\title{
Research
}

\section{The Ghost of Development Past: the Impact of Economic Security Policies on Saami Pastoral Ecosystems}

\author{
${ }_{\text {Vera H. Hausner }}{ }^{1}$, Per Fauchald $^{2}$, Torkild Tveraa $^{2}$, Elisabeth Pedersen $^{2}{ }^{\text {, Johnny-Leo Jernsletten }}{ }^{3}$, \\ $\underline{\text { Birgitte Ulvevadet }}^{1}, \underline{\text { Rolf A. Ims }}^{1},{ }_{\text {Nigel G. Yoccoz }}{ }^{1}$, and Kari Anne Bråthen ${ }^{1}$
}

\begin{abstract}
To ensure economic viability over time, any efforts to meet the Millennium Development Goals need to reconcile conservation with development interventions. Particularly, in marginal and risk prone areas erosion of resilience could make production systems more susceptible to environmental risks that compromise the economic security. By longitudinal analyses of long-term data records we investigated the impacts of big push policies on Saami pastoral ecosystems in Arctic Norway. The big push was accompanied by reindeer herd accumulation and a corresponding degradation of resilience, increasing the susceptibility to herd losses to predators and adverse winters. For the last 20 years the Norwegian government has worked to halt degradation of pasture ecosystems and reduce susceptibility to environmental risks. These intended win-win policies have mainly been based on economic incentives, which have been developed together with Saami pastoralists through negotiated agreements. We argue that the continued degradation of the Saami pastoral ecosystems is a "ghost of the development past", as the big push policies have resulted in an economic security trap (EST). The gradual reduction of resilience has persisted as the ex post payments of disaster relief and predator compensation have impeded the long-term actions to reduce susceptibility to environmental risks, i.e., ex ante policies, thereby increasing dependency on elevated economic inputs to manage the risks. The transfer of liability for managing risks to the benefactor, both through ex ante and ex post policies, has further discouraged and constrained opportunities for adaptation by the pastoralists.
\end{abstract}

Key Words: big push; development policies; economic security trap; environmental risks; pastoralist ecosystems; resilience; Saami; tundra; win-win

\section{INTRODUCTION}

Human interventions that change ecosystems to improve human welfare could lead to unintended feedbacks and consequences for other ecosystem services, including those important for local livelihoods (Millennium Ecosystem Assessment 2005, Chan et al. 2007). Crucial is the maintenance of resilience, which ensures the ability of producers to cope with recurrent disturbances and provide production opportunities over time (Bennett and Balvanera 2007). Central to resilience thinking is the nonlinear behavior of social-ecological systems (SES) as coupled ecological and social systems (Folke 2006). SES emphasize that ecosystems cannot be understood separately from the human activities and decisions that shape the ecosystem, and social systems are dependent on the long-term capacity of ecosystems to sustain human activities. Key elements of resilience thinking are the ability of SES to tolerate shocks and regenerate after disturbance, and the potential for human activities to cause abrupt shifts to new and fundamentally different regimes. Gradual loss of resilience may push the system closer to a threshold, reducing the likelihood of SES to cope with and recover from shocks and stresses. Such SES could be susceptible even to small-scale disturbances, resulting in sudden and potentially irreversible shifts to alternative regimes, which may be desirable or undesirable for producers, communities, or decision makers. 
One example of such undesirable regimes are poverty traps, which can be thought of as a minimum threshold for assets or income, below which people are unable to build productive assets, educate their children, improve their health and nutrition, and increase income over time (Carter and Barrett 2006). Producers are in such cases unable to buffer shocks or overcome persistent low income situations and consequently remain in poverty. States of persistent poverty are particularly prevalent in marginal environments with few exploitable natural resources of low and variable productivity (UNDP 2007). Deprivation is caused by the direct effects of environmental risks that cause substantial losses in income, productive assets, and consumption, but also indirectly by the self-reinforcing mechanisms associated with longterm adaptations to environmental risks, i.e., ex ante, or the short-term actions or coping mechanisms to adverse environmental events, i.e., ex post (Osbahr et al. 2008). In such cases external efforts might be necessary to stimulate selfsufficiency and protect against recurrent environmental risks.

The "big push" approach has been promoted as an effective development intervention to escape poverty traps. It assumes that a temporary boost in public investments is necessary to lift regimes of persistent poverty above the minimum subsistence levels and to higher levels of human development (Sachs 2005, Sanchez et al. 2007). Disaster relief or insurances are further needed to avoid environmental risks pushing households below the subsistence threshold for self-sustainability (UNDP 2007). To overcome development barriers, large-scale investments should be undertaken according to comprehensive plans involving agricultural productivity, health, education, and infrastructure. After the big push the producers are assumed to have the sufficient skills, capital, and means to move toward self-sufficiency. The big push approach has been criticized for not paying sufficient attention to failures of previous efforts of large-scale development (Easterly 2006). Large-scale, centrally controlled investments may be less effective to accomplish development and conservation goals than flexible, small-scale interventions that allow for learning and adaptations over time (Nelson 2009). Furthermore, to avoid big pushes shifting the SES to another undesirable state, attention must be paid to the ecosystems potential to support these changes as well as to the risks of creating cycles of dependencies and disincentives for self-sufficiency (Kofinas and Chapin 2009, Chapin et al. 2010).
In Saami pastoral ecosystems in Northern Norway, big push policies were implemented to lift communities to a higher level of human development. From 1976 there was a sudden increase in public investments directed toward modernization of the production system. The reforms included (i) payments to herders and local districts to increase net income, (ii) investments in housing, technology, infrastructure, research, and education, (iii) herd management to increase production per unit area, i.e., intensification, and (iv) disaster funds to compensate extraordinary losses (Riseth and Vatn 2009). When introducing such big push policies, it is crucial to craft policies that fit the ecological dynamics of the environment. Climatic variability and resource fluctuations could conceal gradual changes, such as loss of resilience, that are caused by increased human activities (Ludwig et al. 1993, Cinner et al. 2009). Big push policies therefore need to stimulate adaptation to environmental risks over time, i.e., ex ante policies. However, and as we elucidate in this article, shortterm actions in response to adverse environmental events, i.e., ex post policies, also need to be compatible with the long-term conservation and development goals. Otherwise, such policies may result in what we term economic security traps (EST), a policy-driven situation in which erosion of ecosystem resilience may increase the susceptibility to environmental risks, which in turn may require elevated inputs to ensure economic security.

The aim of this article is twofold. First, we analyzed changes in the Saami pastoral ecosystems by longitudinal analysis of economic security policies as drivers of change in the SES. Second, we elucidated the outcome of past and present policies for the resilience of the current regime. We focused on reindeer numbers and their condition as a surrogate for resilience and losses to predators and climatic risks. By using reindeer as surrogates we can build on long-term data records ( $\sim 60$ years) to analyze the relationships between policies, public investments, resource fluctuations, and condition. The relationship to ecosystem degradation has been published elsewhere, but is briefly summarized in Appendix 1 to clarify the relationship between reindeer numbers, condition, pastures, and losses associated with environmental risks. In addition, there are several studies demonstrating broader ecosystem consequences that appear to compromise goals for conservation and maintenance of ecosystem services (e.g., Suominen and Olofsson 2000, Bråthen et al. 2007, Ims et al. 2007, Tømmervik et al. 2009). These broader ecosystem 
consequences may be of importance in the long term, but in this study we narrow our scope to livelihood resilience in Saami pastoral communities, which are reliant on reindeer both economically and culturally (Riseth 2006). Thus, in our case, livelihood resilience to environmental risks is coupled to the likelihood for losses of reindeer to adverse events, as well as the ability of households and communities to cope with and recover from such events. To analyze both the economic security policy as a driver of change and livelihood resilience, it is necessary to combine multiple methods and data sources including archival data, official electronic databases, policy analysis, and interviews.

\section{METHODS}

\section{The study system}

The Saami pastoral ecosystem covers $40 \%$ of the Norwegian mainland $\left(\sim 140,000 \mathrm{~km}^{2}\right.$; Reindeer Husbandry Administration 2008). The present study focuses on the Kautokeino region, which encompasses $45 \%$ of the Saami pastoralists in Norway. Most of the pastoralists move between inland winter pasture and summer pastures near the coast. Winter areas are characterized by a stable and dry climate, yet the reindeer herds are highly vulnerable to adverse snow conditions in late winter (Tveraa et al. 2007). The winter pastures have not been formally divided in land tenures, but family groups (siida) have traditionally moved to defined pasture areas, with some flexibility to move beyond boundaries under adverse climatic conditions (Paine 1994).

The summer pastures are divided into local districts with boards representing the pastoralist families that graze in that area (Ulvevadet 2008). Within these local districts there are operation units, which are licensed entitlements to practice reindeer husbandry. The payments to Saami pastoralists are channeled through the local districts and the operation units. The comanagement system, organized in national, regional, and local boards, regulates operation units, reindeer numbers, and access to different pastures (Ulvevadet 2008, Riseth and Vatn 2009). The public investments in Saami pastoral communities are, however, regulated by the General Agreement for the Reindeer Industry. The agreement is a result of negotiation between the government and the Saami Reindeer Herders'
Association (Ulvevadet 2008, Riseth and Vatn 2009). The comanagement boards and the negotiations have been a part of the governance system since the 1978 Reindeer Management Act, which means that Saami pastoralists have participated in policy making. The exceptions are extraordinary disaster funds established by the Norwegian Parliament to compensate for abnormal winter losses, or predator compensations that are handled by the environmental authorities.

Claims for compensations of losses owing to predation by nationally protected large carnivores, such as wolf (Canis lupus), wolverine (Gulo gulo), brown bear (Ursus arctos), lynx (Lynx lynx), and golden eagle (Aquila chrysaetos), are managed by the environmental authorities together with the Reindeer Husbandry Administration (RHA). Compensations are provided on the basis of documented losses combined with official assessments of the likelihood for losses. In the past, carnivores were removed to ensure protection of livestock, but were protected by law in 1970 . However, regulations do not allow wolves to establish packs within reindeer herding areas, wolverines are not allowed to reproduce within reindeer calving areas, and lynx and wolverines are still culled to protect the reindeer herds.

\section{Policy analyses}

All the provisions were analyzed with regard to objectives and requirements. The payments were divided into four categories on the basis of their main purpose (see Appendix 2). The main purpose of operating subsidies is to improve living standards by covering the costs of managing operation units or local districts. The subsidies could include production requirements, but the main intention is to ensure a higher net income for pastoralists. Production subsidies aim to stimulate increased production and deliveries to slaughterhouses, as well as to spare winter pastures. Preventive measures are targeted toward reduction of losses to predators or adverse climate, and finally, compensations cover abnormal losses on winter pastures and losses to predators. The payments within these categories were analyzed using linear models to estimate the effect of total disbursement on harvest rates and relationship to slaughter income. Policy analysis of official reports and propositions was conducted to identify: (i) development policies, as well as the rationale behind 
the policy instruments chosen, and (ii) the ex ante and ex post policies directed toward predator and climatic risks. These analyses were used to interpret the shifts in public investments over time.

\section{Public investments}

Electronic databases on payments were available from 1991 to present. Records on payment from 1980-1991 were collected from the paper archives of the RHA. From 1950 to 1979 investments were reported by the Saami bailiff, the attendant for the Norwegian government before the establishment of the RHA. In this period a few of the subsidies were managed by slaughterhouses and had to be calculated based on provisions and deliveries to slaughterhouses (see Appendix 2). The Directorate for Nature Management has electronic databases on predator compensation, but for the period prior to 1981 we collected data from the paper archives. All payments were adjusted according to the 2008 consumer price index published on Statistics Norway's web page (www.ssb.no/english) and converted to USD. We did not include indirect payments, such as public investments in houses, fences, transport, education, and slaughterhouses, as well as access to cheap credit and tax and duty exemptions. Subsidies other than for reindeer meat or by-products have not been substantial and are therefore not included in the analyses.

The number of families and owners was available in the Saami bailiff reports until 1978, and was later reported as licensed herding units by the Economic Committee for Reindeer Husbandry. It is important to keep in mind that a strong initial increase of herding units relative to number of families could be dependent on the licensing practices of the area boards, which we therefore checked in this study.

\section{Harvest rates and carcass mass}

The income of Saami pastoralists is dependent on reindeer abundance, which fluctuates according to productivity on summer pastures, winter herd losses, and harvest rates (Tveraa et al. 2007, Riseth and Vatn 2009). Reindeer abundance was provided by the RHA, which has electronic databases on reindeer numbers in spring before calving from 1945-2008. Harvest rates and income from reindeer meat were reported by the Saami Bailiff until 1979 and thereafter by the Economic Committee for
Reindeer Husbandry. Reliable data on harvest rates are not available before 1970 .

The most immediate ecological outcome of herd accumulation was examined by longitudinal analyses of reindeer carcass mass. Carcass mass is a critical parameter for survival and reproduction of large ungulates, and calves in particular have been proposed as an efficient indicator for managing large ungulate populations (Morellet et al. 2007). Carcass mass is not only an indicator of the availability of pasture resources, but is also an indicator of ecological resilience, because reduced weight increases susceptibility to losses in adverse winters as well as to predators (see Appendix 1). The higher likelihood of losses due to lower weights indicates that the Saami pastoral ecosystems have a lower ability to cope with disturbances, which implies reduced livelihood resilience for the herders.

Since 1981, calf weights were publicly available from the RHA, but before 1981 data on calf weights are limited, mainly because of the cultural practice of not slaughtering calves during this time period. There are, however, studies that report weights of 1.5-year-old males from 1961-1963 (Movinkel and Prestbakmo 1968), and we also found records from 1973-75, 1977, 1981, and 1982 in the paper archives at the RHA. Since 1996, weight data on both calves and 1.5-year-old males are available. The carcass mass of 1.5-year-old males should reflect the quality of the pastures when the animals were calves (their first summer) and the following winter and summer. Accordingly, there was a strong positive relationship between the weight of 1.5-year-old males and the weight of calves the same year combined with the weight of calves the year before: $m=3.81+0.40 c_{0}+0.82 c_{1}, \mathrm{R}^{2}=0.97, \mathrm{n}=11$, where $m$ is the weight of 1.5 -year-old males, $c_{0}$ is the weight of calves the same year, and $c_{1}$ is the weight of calves the year before (when the 1.5-year-old males were themselves calves). We used this relationship to predict the weights of 1.5-year-old males from the weights of calves in the period when data on 1.5-year-old males were missing (from 1982-1995). Because the carcass weight of 1.5year-old is a proxy for pasture quality the year the males were slaughtered as well as the year the males were calves, we included a one year time lag in the analyses of the relationship between animal density and carcass mass. 


\section{Interview inquiry}

The interviews were designed to understand spatial and temporal differences in the Saami pastoral communities that underlie reindeer abundance and productivity (Appendix 3). Environmental risks were one of several thematic areas covered in the interviews. Others were governance, symbolic and social capital, herding practices, and economic organization. The study included 77 Saami pastoralists from 20 of the 34 local districts that have winter pastures on common grazing lands. The interview inquiry was limited to the period after the big push. We used published literature in combination with the interviews to reflect on the current practices of Saami pastoralists to prepare for, cope with, and recover from adverse winters.

\section{RESULTS}

\section{The big push policies}

After World War II, more than $50 \%$ of the Saami pastoral families in Finnmark County owned fewer than 200 reindeer, which was regarded as a subsistence minimum with few possibilities for herd or capital accumulation (Saami Bailiff Reports 1950-1979). During the 1960s and 1970s, development policies were gradually implemented to improve the pastoral family economy. The policies aimed to bring welfare to Norwegian standards, as well as to even out differences in herd sizes among Saami pastoral families (Paine 1994). The public investments were largely influenced by the recommendations of the Saami committee, which was appointed by the government to suggest measures for improving the economic and cultural status of the Saami communities (Norwegian Ministry of Church Affairs and Education 1959, Kalstad 1999). Among the concerns was the future recruitment to reindeer husbandry because of the hard working conditions and low living standards. The committee therefore suggested investments in housing, slaughterhouses, roads, restocking, fences, vocational training in reindeer pastoralism, education, research, and administration. While raising living standards, the public investments also resulted in rapid cultural changes of the Saami pastoral communities (Paine 1994, Kalstad 1999). The houses were built in a few settlements, and increased the distances between the family and the seasonal pastures. As a result the male pastoralists started to commute between pastures and the settlement by use of motorized vehicles. Some pastoralists also privatized shared pastures by setting up fences, thus reducing the need for continuous herding. The costs of housing, maintenance of fences, and motorized vehicles subsequently increased the need for monetary income, which could be achieved through the spouses' wage income, governmental subsidies, and/or by increasing production of meat for the market. Meat production for the market was further encouraged by the big push policies of the 1970s, which aimed at rationalizing reindeer herd management by increasing efficiency and herd productivity (Paine 1994).

At the beginning of the 1970s, higher expectations of oil revenues encouraged higher investments in rural development programs in northern Norway, partly to counteract increasing demands and income in urban areas (Ministry of Agriculture 1974). Consequently the big push toward modernization commenced (Ministry of Agriculture 1976), including operating grants to reindeer herders to reduce costs, thereby improving the living standard (Fig. 1c,d, Appendix 2). Besides operating grants, the investments included guaranteed minimum prices and price subsidies, as well as indirect subsidies to slaughterhouses and transport. These reforms aimed at modernizing and increasing production, at the same time as ensuring sustainable resource use. The economic policies were based on negotiated agreements between the Norwegian government and the Saami Reindeer Herders' Association, and were modeled according to the agricultural policies already in place for farmers (Paine 1994, Kalstad 1999). Traditionally it was common for family members to exit pastoralism in favor of other livelihoods or adopt a peasant strategy that combined reindeer herding with fisheries or small-scale agriculture (Paine 1994, Olsson and Lewis 1995, Riseth 2006). The big push policies created disincentives for such livelihood adaptations because subsidies were directed toward meat production and disregarded other sources of income associated with the Saami pastoral communities. Specialization was further encouraged by the 1978 Reindeer Management Act that defined Saami pastoralism as an occupation, and established licensed herding units (driftsenhet) through which the payments were channeled. The subsidy programs required that one person in the family was fully engaged in reindeer husbandry. The combined effects of sedentarization, motorized vehicles, and economic rationalization also changed the 
traditional family-based herding practices, which were founded on stronger engagement by all family members in daily activities related to herding and utilization of other reindeer-related products, such as skin and antlers (Paine 1994, Kalstad 1999).

The big push increased recruitment to reindeer pastoralism (Fig. 2). Most applicants, usually men, who fulfilled the requirements in 1979 of income statement and sufficient reindeer numbers $(>100)$ were automatically licensed (Area Board, West Finnmark, unpublished Minutes of Meetings, 1982-87). Only 3\% of the applicants were rejected before 1987, whereas most were rejected thereafter. Many households were granted more than one license before 1987, which apparently had increased subsidies per family (Berg 2000). The official politics was to ensure the rights of pastoralists to continue their traditional way of life, and the government was therefore reluctant to control entry into the occupation (Paine 2006). The Department of Agriculture did, however, provide financial assistance to pastoralists who would exit the occupation, but few accepted the offer. Furthermore, the additional sources of income combined with favorable and stable winter climates allowed for low harvest rates resulting in an increase in reindeer numbers from 40,000 in 1969 to a peak of 112,000 in 1989 (Fig. 1b; Paine 1994, Riseth and Vatn 2009). After 1987 the number of licenses has declined, but the number of family members who own reindeer in each unit continued to increase.

\section{Win-win policies}

Concerns about the rapid increase of reindeer herds, reduced weights, and degradation of lichen winter pastures resulted in a second major policy shift in 1989. The government and the Saami Reindeer Herders' Association agreed that ecological sustainability is a prerequisite for economic development, and introduced production subsidies that rewarded higher harvest rates. Harvest requirements had been a part of the operating subsidies, but were secondary to the major aim of covering the costs of an increasingly modernized reindeer pastoralism. These new subsidies aimed for win-win outcomes by enhancing efficiency of meat production per hectare. The policies were directed toward increasing the proportion of productive females in the herds, as well as reducing risks of losing animals on winter pastures
(Appendix 2). Such win-win policies were also emphasized by a White paper (Ministry of Agriculture 1992a) and the subsequent Parliament resolution (Ministry of Agriculture 1992b). The long-term goal was to balance ecological, economic, and cultural sustainability by adjusting number of reindeer and Saami pastoralists to the pasture capacity. To reach these goals the economic incentives were designed to increase total harvest rate, proportion of calves harvested, and to encourage slaughter of reindeer before entering the winter pastures (Appendix 2). It was assumed that higher production per animal would allow for higher income per household and protect pastures, thereby allowing more pastoralists to stay in business. The national and regional comanagement boards were given the responsibility to set the maximum number of reindeer and to regulate the number of herding unit licenses, but the production subsidies coupled with harvest requirements continued as the major policy instrument to reach the goals.

\section{Policies toward environmental risks}

Before the onset of big push there were adverse weather events in 1958, 1962, and 1968, when too much snow in late winter caused substantial reductions in reindeer populations (Saami bailiff reports, 1950-1979). A disaster fund that included both ex ante preventive measures and ex post compensations for abnormal losses was established in 1976. The disaster fund had strict requirements, and combined with stable and favorable winters, it was hardly used in the big push period (Fig. 1c, Appendix 2). The compensation payments in this era were mainly issued for losses to predators. However, subsequent to catastrophic winters with heavy snowfalls in 1997 and 2000, compensations for winter losses were high, and, together with a considerable increase in predator compensations, the total disbursement yielded far more than has ever been given in subsidies.

Since 1989, production subsidies that aimed to change herding practices to higher harvest rates, calf slaughter, and autumn slaughter have been the dominating ex ante policies (Appendix 2). In the first three years, extra production subsidies were provided to rapidly increase harvest rates (Fig. 1c). In recent years there has been a small increase in ex ante preventive measures only aimed at reducing susceptibility to losses, such as crisis fodder, alternative migration routes and pastures, shepherd 
Fig. 1. Time course featuring the relationship between economic security policies, harvest rates, reindeer abundances, and carcass mass. Dashed vertical lines indicate major policy shifts. The postwar period was characterized by economic deprivation. Welfare policies started in the 1960s, but the big push was initiated with the first General Agreement for the Reindeer Industry in 1976. Sustainability measures were introduced in 1989, and the subsequent period has been characterized by ex ante and ex post policies toward environmental risks. (a) Reindeer abundance (herd size in spring before calving) and carcass mass. (b) Reindeer abundance and percent annual harvest (animals slaughtered in percent of herd size before calving). (c,d) Operating costs (blue) dominate in the big push period. Production subsidies and preventive measures (red) work mainly ex ante, whereas compensations work ex post (green). (c) Total disbursement in USD (adjusted according to the $2008 \mathrm{CPI}$ ). (d) Time period for disbursement of the different subsidies and compensations (see Appendix 1 for detailed descriptions of time period, requirements, and quality of the data).

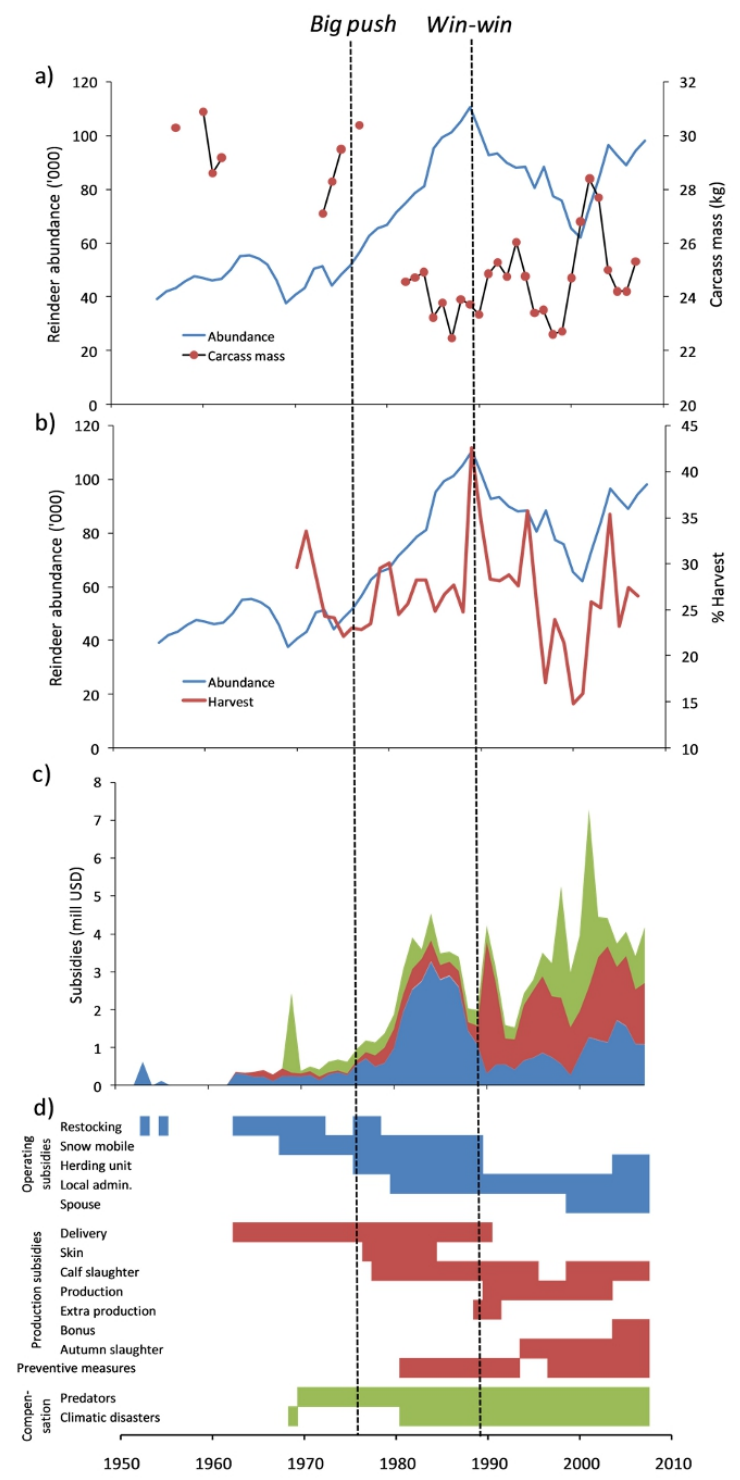


Fig. 2. Time course of the number of Saami families/herding units (hatched, blue) and number of pastoralists (solid, red).

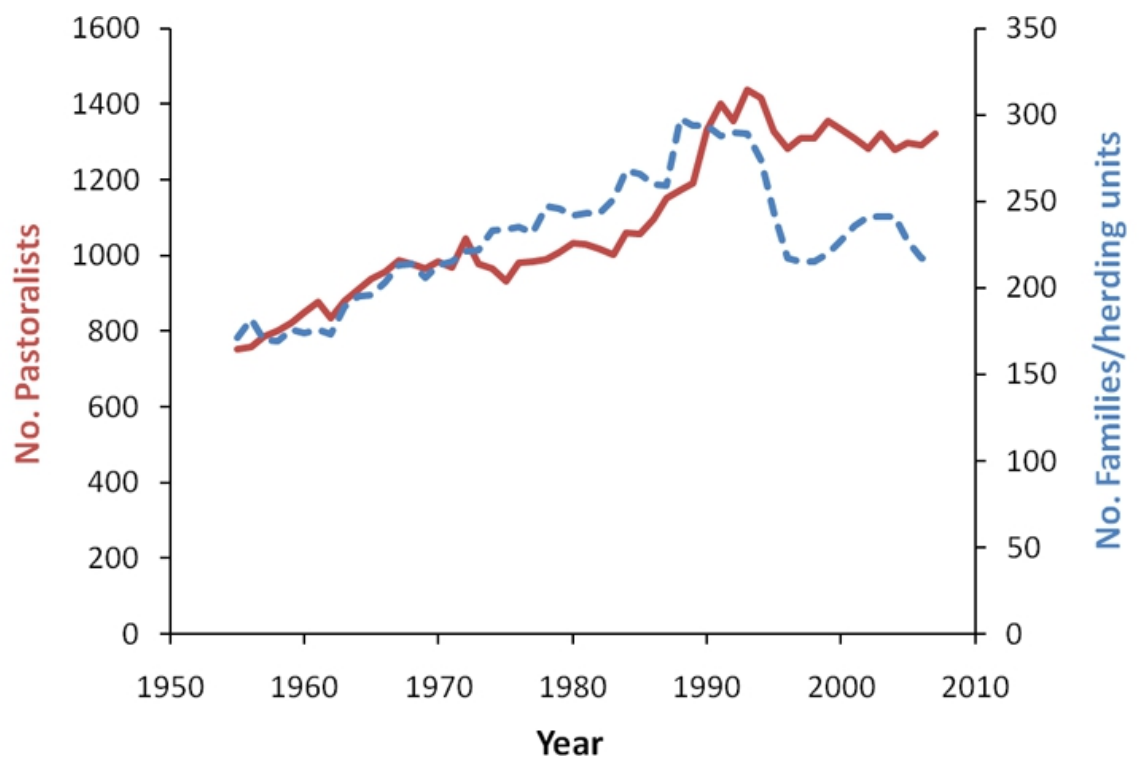

dogs, fences, or extra personnel for herding. Compared with the production subsidies, however, payments for preventive measures have been negligible.

In short, payments from the government have served three main purposes: (i) operating subsidies to increase living standards, (ii) production subsidies to increase harvest and thereby reduce losses, i.e., ex ante policy, and (iii) compensation for losses to reduce the effects of adverse weather and predators, i.e., ex post policy. The shifts in the use of the different instruments reflect the major changes in policy from the big push to the win-win (Fig. 1c,d).

\section{Harvest rates and carcass mass}

The period since 1989 has been characterized by irregular harvest and a variable production (Fig. 1a, b). Three periods of high harvest rate (> 35\%) occurred after the big push $(1989,1995$, and 2004; Fig. 1b). These periods were associated with generally high reindeer numbers and high production subsidies. Two periods of exceptionally low harvest rate $(<20 \%)$ occurred after the two catastrophic winters with high snow accumulation on winter and spring pastures (1997 and 2000). The adverse winters caused substantial losses for the reindeer herders, but the economic losses were largely compensated ex post directly by the authorities (Fig. 1c). After the winter of 2000, reindeer numbers increased again from 62,000 and peaked at 96,000 in 2003. Accordingly, the dynamics of ex ante and ex post policies were closely linked to the fluctuations in harvest rates and reindeer numbers, because the public expenditures on subsidies and compensations alternately stabilized the income for reindeer herders. The total governmental disbursement $(D)$ was accordingly inversely related to slaughter income $(S)$ since 1989 (linear model: $D=40.2-0.58 \times S, R^{2}=0.49, n=$ $19, P=0.001)$. The relationship was weaker in the big push period (linear model: $D=27.7-0.28 \times S$, $\left.R^{2}=0.06, n=13, P=0.43\right)$.

The decline in carcass mass of 1.5 -year-old reindeer is evident in the historical records, ranging from more than $30 \mathrm{~kg}$ before the big push to less than 24 kg after 1989 (Fig. 1a). Accordingly, carcass mass was inversely related to reindeer numbers (linear regression with carcass mass $[B M$; response variable] lagged with one year after reindeer number $[N$; predictor variable $]: B M=33.8-1.04 \times 10^{-4} \times N$, 
$\left.R^{2}=0.72, n=34, P<0.001\right)$. In the period after the big push the fluctuation in reindeer numbers has temporarily increased carcass mass, but this has been followed by a new period of increase in reindeer number and subsequent decrease in carcass mass.

\section{Resilience of the Saami pastoral ecosystem}

The most obvious consequence of herd accumulation has been the degradation of lichen pastures in wintering areas in the period 1961-2000, whereas a moderate increase was detected around the millennium shift because of lowered populations in the 1990s (Tømmervik et al. 2009). Tømmervik et al. (2009) also suggested that the removal of the barrier effect of the thick lichen cover has promoted growth of the mountain birch (Betula pubescens) forest on winter pastures. Recent studies have also documented effects of herd density on ecosystem productivity on summer pastures (Bråthen et al. 2007), as well as on other herbivores (Ims et al. 2007). High reindeer density increases the susceptibility to environmental risks, because reduced body condition increases the likelihood for losses to adverse winters as well as to predators (see Appendix 1). Loss of pastures to development in the big push period was probably important near regional centers. However, $78 \%$ of the total land area and $84 \%$ of the winter pasture area in Finnmark is still largely undisturbed $(>1 \mathrm{~km}$ from encroachment; Norwegian Directorate for Nature Management, INON, version 01.08., www.dirnat.no/ inon). Although encroachment might have played a part, the increase in reindeer numbers during the big push period was a major driver resulting in loss of resilience through pasture degradation and increased susceptibility to adverse winter conditions. The efficiency of carcass mass as an indicator of pastoral ecosystem conditions has also been supported by a governmental task force of scientists, reindeer herders, and managers, as well as by $70 \%$ of the reindeer herders that we interviewed.

The pastoralists in our interviews expressed concern for adverse winters such as those of 1997 and 2000, when heavy snowfall hindered access to pastures thereby resulting in mass starvation (see Appendix 1). These situations were described as social tragedies, as pastoralists desperately attempted to gather the herds, provide crisis fodder, and move to alternative pasture areas. To adapt to adverse winters, more than $90 \%$ of interviewees maintained that slaughtering of calves and weak animals would improve herd condition and reduce susceptibility to losses. In other words, they did not regard herd accumulation as the major strategy for selfprotection against environmental risks, but to pursue ex ante strategies, they depend on collaboration with the surrounding pastoralists. As argued by the majority of reindeer herders in our interviews, the big push resulted in a gradual breakdown of informal grazing tenures in the winter grazing areas and more competition for pasture resources. Of those interviewed, 83\% reported tensions with neighbors because of overlapping use of grazing resources. Scarcity or tensions on winter pastures was defined as the bottleneck for reindeer herding by most of the pastoralists. The increased overlap has also reduced the flexibility to move to alternative pastures. Artificial feeding has not become a usual practice, with only $12 \%$ feeding on a permanent basis. However, $39 \%$ maintained that small amounts of fodder were given in limited time periods to ensure that the reindeer would tolerate crisis fodder in adverse winters.

Modern reindeer husbandry has increased the costs associated with reindeer herding, which put higher demands on income levels (Riseth 2006). While conducting our interviews in 2007, as much as $46 \%$ of the income in the Kautokeino regions was from governmental inputs such as subsidies (29\%), compensations for losses $(11 \%)$, and pasture loss (6\%; Karlstad and Lie 2009). Subsidies have been targeted toward increased specialization on meat production. These policies have influenced the economic adaptations of the households. In our interviews, $73 \%$ maintained that meat production was a primary motivation for their husbandry practices, whereas only $12 \%$ perceived production for a market as unimportant, a result that contrasted with earlier description of livelihood adaptation among Saami pastoralists (Paine 1994). Furthermore, there were only $12 \%$ who reported any substantial supplementary income from reindeer related products. In general, supplementary income from Saami handicraft, berries, hunting, and fishing was rather low, only $2.3 \%$ in 2007 (Karlstad and Lie 2009). Although it appears that Saami pastoralists are highly dependent on governmental input and meat production, the costs are also covered by wage income. Among those interviewed $60 \%$ reported wages from spouses as an important part of the household income. Today, mostly men are working daily with the herds, while both the wife and the 
children are participating in work intensive periods. Only 3 males of those we interviewed combined wages with reindeer herding. The changes have made reindeer herders highly specialized, but the spouse's wage income and subsidies increase abilities of the majority of pastoralists to cope with disturbances. The ex post payments also allow for fast recovery rate subsequent to adverse winters (Fig. 1).

\section{DISCUSSION}

The big push for welfare in the Saami pastoral community aimed to lift the SES above the minimum subsistence level to higher levels of human development. The policies were rooted in social democratic ideals characteristic of the Nordic welfare state, emphasizing equitable status of citizens and equal distribution of wealth and income (Paine 1994, Olsson and Lewis 1995). The big push policies had unintended consequences of herd accumulation, and the decline in resilience has made the Saami pastoral communities more susceptible to losses to predator and adverse winters (Fig. 1, Appendix 1). To maintain the living standards and the modernized herding practices achieved after the big push, certain levels of external economic input were necessary. Similar policies focusing on rationalization of herd management have also been implemented in the other Nordic countries, Finland and Sweden, and have made pastoralists more dependent on meat production for the market to cover costs (Forbes et al. 2006). The win-win policies introduced in 1989 aimed to reconcile economic and ecological sustainability. Concurrently, the payments to Saami pastoralists were linked to harvest rates, and to calf and autumn slaughter through production subsidies, which have been the major form of ex ante policies directed toward environmental risks. These policies have resulted in variable and low production, in which Saami pastoralists have found it timely to harvest in some years, yet the practice of herd accumulation has continued the following years, thus keeping ecosystem resilience persistently low. The increased susceptibility does not come at expense of economic security as ex post disaster relief and predator compensations buffer economic losses.

On the basis of these results we argue that the big push policies have resulted in an economic security trap (EST). EST occurs when policies that protect against economic deprivation enhance the susceptibility to environmental risks. The loss of resilience necessitates further protection against risks, thus gradually shifting the liability for ex ante and ex post approaches to the benefactor. Such economic security policies create vicious circles that may temporarily secure the economic income of beneficiaries, but in the long term, environmental disasters may hit harder when adversities occur. In other words, the maladaptive policies may trap people in a system that becomes increasingly more susceptible to environmental fluctuations thereby compromising the economic viability over time. Similar mechanisms have been suggested by Bennett and Balvanera (2007) as intensification of agricultural production that increases vulnerability to climate change and pests can lead to dependency on elevated economic inputs to manage risks. Production systems with a high degree of environmental fluctuations increase the likelihood of such feedback mechanisms, because gradual erosion of ecosystem resilience is hard to separate from increased environmental variation (Ludwig et al. 1993, Cinner et al. 2009). An analogue to our case is overexploitation of fluctuating fish populations described by Ludwig et al. (1993). Unrestricted investments in fishing fleet capacity in relatively stable years are often economically compensated for in adverse years, resulting in a net overcapacity and overharvest of the resource over time. Likewise, the big push of Saami pastoral communities has built up a production system with too many animals in climatically favorable years, for which increased losses in adverse years have been compensated by ex post payments, resulting in persistently low resilience.

After a big push, producers are expected to move toward self-sufficiency, because modernized production processes allow higher productivity and product diversity (Sanchez et al. 2007). In the case of decreased resilience, the independence of public transfers may fail to materialize because of the need to buffer economic losses under adverse conditions (Beier et al. 2009). Without exit strategies big push policies may create cycles of dependencies and disincentives for self-sufficiency (Kofinas and Chapin 2009, Chapin et al. 2010). In our case the disaster relief and predator compensation provide extra economic input that reduces the economic risks of herd accumulation. Subsidized risk management tends to work against other policy measures, as economically secure producers could afford greater risks to obtain greater productivity and higher returns (Goodwin and Vado 2007, 
UNDP 2007). The ex post payments may therefore counteract work toward self-protection that could potentially lower the risks among all producers.

When policies do not work it may be attributed to incongruence in values, knowledge, or perceived risks (Adger et al. 2009). In pastoral production systems, herd accumulation is often perceived as an insurance against environmental risks, which was also traditionally the case for the Saami pastoralists (Paine 1994, Riseth and Vatn 2009). The interviews of the herders are not consistent with this view because as many as $90 \%$ maintain it would be better to prepare for adverse winters by taking out calves and weak animals to reduce susceptibility to losses. Such a strategy is, however, dependent on neighbors doing the same, because the likelihood of loosing reindeers depends on the surrounding herd density on the shared pastures (Næss and Bårdsen 2010). If the other pastoralists do not reduce their herds, individual owners will still benefit from owning larger herds. The herders emphasize that herd accumulation strengthens their position on common pastures in climatically favorable years. As is known from other pastoral production systems, the present competition for common pastures could be a result of the breakdown of informal tenure systems induced by external pressures (Borgerhoff Mulder and Coppolillo 2005), which in our case were the big push policies. In this period the payments were used for herd expansionism (Riseth and Vatn 2009). The positioning on winter pasture may thus constrain opportunities for ex ante strategies to environmental risks. The investments have also increased the recruitment (Fig. 2) and overlap in seasonal pastures, which limit coping responses in adverse winters. Reduced mobility and opportunities for flexible use of reserve pastures is well known to erode resilience by reducing the ability to prepare for and cope with adverse events in pastoral systems (Forbes et al. 2009, Robinson and Berkes 2010).

Besides herd management, economic diversification is widely recognized as a risk aversive strategy in resource-dependent communities, because the production gains of specialization are traded against the greater security afforded by spreading risks (Ellis 2000). In the big push period, reindeer pastoralism was defined as an occupation and demanded full engagement in reindeer herding, deemphasizing supplementary sources of income. On the one hand, the strong degree of specialization in reindeer meat production has reduced resilience of households to environmental risks. Besides increasing the likelihood for losses, the pastoral specialization has reduced the opportunities to adapt by extensification, migration, or flexible use of pastures because of the lack of vacant pastures (Riseth and Vatn 2009). On the other hand, for the majority of the Saami pastoral households, the public sector provides opportunities for diversification through education and wage labor (Reindeer Husbandry Administration 2009), which together with the ex post payments allow for faster recovery after disturbances and increase the potential for adaptation to changes.

Public investments in Tongrass National Forest in Alaska have resulted in a similar situation because economic variability has subsequently been buffered by the government (Beier et al. 2009). The trap was explained by rigidity in governance, whereby the command-and-control approach by the forestry sector impeded adaptations to societal demands. In our case the public investments were negotiated with reindeer herders, and the comanagement system has had a major responsibility for regulating access to pastures, recruitment, and reindeer numbers (Paine 2006, Ulvevadet 2008). Although governance of the Saami pastoral ecosystems may not qualify as a command-and-control approach, large-scale investments have been directed toward one resource, which has created disincentives to diversify and adopt ex ante strategies.

\section{CONCLUSION AND BROADER IMPLICATIONS}

In marginal and risk prone areas, big push policies could gradually erode resilience, thereby increasing dependency on elevated economic inputs to manage the risks. The transfer of liability for managing risks to the benefactor, both through ex ante and ex post policies, may further discourage self protection by the producers. To avoid EST, such plans need to include ex ante policies that encourage selfprotection against environmental risks, whereas short term actions after environmental disasters, $i$. e., ex post payments, also need to comply with longterm goals. In our case the ex post payments of disaster relief and predator compensation have partly impeded the long-term actions to reduce susceptibility to environmental risks, that is, ex ante policies. However, ex ante policies that increase external economic input could also have contributed to the maintenance of EST. The result has been 
persistently low resilience in terms of higher likelihood for losses and reduced flexibility to move to vacant pastures for pastoralists. On the other hand, ex post payment and the spouse's wage income buffers the economic consequences of adverse events.

In recent years there have been policy changes attempting to deal with the increasing numbers of reindeers. Instead of using economic incentives as a major instrument to reach ecological sustainability, there has been more emphasis on regulatory approaches (Ulvevadet and Hausner 2011). The 2007 Reindeer Management Act devolves more responsibilities to the siida to make their own rules for reaching sustainable goals, whereas sanction possibilities by the comanagement boards and the government have been strengthened (Ulvevadet 2008). Voluntary programs to divide shared winter pastures into siida tenures have also been attempted. The latest suggestion by the government, dated 4 May 2011, is to remove regional comanagement boards, which will reduce the multilevel comanagement system to a national and a local level. New laws and regulations are one trajectory for dealing with EST, but there are alternative paths that may not have been sufficiently explored. The multilevel comanagement system could profit by integrating the principles of adaptive management that allow for systematic monitoring and learning from human interventions in ecosystems (Lee 1993, Olofsson 2011). In marginal and risk prone areas the high uncertainties of human impacts on ecosystems make monitoring, learning about, and adaptation to ecosystem changes even more important. Adaptive comanagement seeks to bridge the principles of adaptive management and comanagement (Armitage et al. 2007), and could create arenas for mutual learning and trust building that may represent an alternative trajectory for escaping the EST.

Responses to this article can be read online at: http://www.ecologyandsociety.org/voll6/iss3/art4/responses/

\section{Acknowledgments:}

We are grateful to the Ministry of Agriculture and Food, the Reindeer Husbandry Administration, the Directorate for Nature Management, and slaughterhouses for providing historical records for the study. We also thank the Saami pastoralists that participated in the interviews. This study was a part of the "Ecosystem Finnmark" project, financed by the Norwegian Research Council.

\section{LITERATURE CITED}

Adger, W. N., S. Dessai, M. Goulden, M. Hulme, I. Lorenzoni, D. R. Nelson, L. O. Naess, J. Wolf, and A. Wreford. 2009. Are there social limits to adaptation to climate change? Climatic Change 93:335-354. http://dx.doi.org/doi:10.1007/s10584-0 $\underline{08-9520-\mathrm{Z}}$

Armitage, D., F. Berkes, and N. Doubleday, editors. 2007. Adaptive co-management: collaboration, learning, and multi-level governance. University of British Columbia Press, Vancouver, British Columbia, Canada.

Beier, C., A. L. Lovecraft, and F. S Chapin, III. 2009. Growth and collapse of a resource system: an adaptive cycle of change in public lands governance and forest management in Alaska. Ecology and Society 14(2): 5. [online] URL: http://www.ecology andsociety.org/vol14/iss2/art5/

Bennett, E. M., and P. Balvanera. 2007. The future of production systems in a globalized world. Frontiers in Ecology and the Environment 5:191-198. http://dx.doi.org/10.1890/1540-9295(2007) 5[191:TFOPSI $] 2.0 . \mathrm{CO} ; 2$

Berg, B. 2000. Mot en korporativ reindrift. Samisk reindrift $i$ Norge $i$ det 20. århundre eksemplifisert gjennom studier av reindriften pà Helgeland. Diedut, No. 3. Nordic Sámi Institute, Kautokeino, Norway.

Borgerhoff Mulder, M., and P. Coppolillo. 2005. Conservation: linking ecology, economics, and culture. Princeton University Press, Princeton, New Jersey, USA.

Bårdsen, B.-J., P. Fauchald, T. Tveraa, K. Langeland, N. G. Yoccoz, and R. A. Ims. 2008. Experimental evidence of a risk-sensitive reproductive allocation in a long-lived mammal. Ecology 89:829-837. http://dx.doi.org/10.1890/07$\underline{0414.1}$ 
Bårdsen, B.-J., T. Tveraa, P. Fauchald, and K. Langeland. 2010. Observational evidence of risksensitive reproductive allocation in a long-lived mammal. Oecologia 162:627-639. http://dx.doi.org /10.1007/s00442-009-1537-0

Bråthen, K. A., R. A. Ims, N. G. Yoccoz, P. Fauchald, T. Tveraa, and V. H. Hausner. 2007. Induced shift in ecosystem productivity? Extensive scale effects of abundant large herbivores. Ecosystems 10:773-789. http://dx.doi.org/10.1007/ s10021-007-9058-3

Carter, M. R., and C. B. Barrett. 2006. The economics of poverty traps and persistent poverty: an asset-based approach. Journal of Development Studies 42:178-199. http://dx.doi.org/10.1080/0022 $\underline{0380500405261}$

Chan, K. M. A., R. M. Pringle, J. Ranganathan, C. L. Boggs, Y. L. Chan, P. R. Ehrlich, P. K. Haff, N. E. Heller, K. Al-Khafaji, and D. P. Macmynowski. 2007. When agendas collide: human welfare and biological conservation. Conservation Biology 21:59-68. http://dx.doi.org/10.1111/j.1523-1739.20 $\underline{06.00570 . x}$

Chapin, F. S., III, S. R. Carpenter, G. P. Kofinas, C. Folke, N. Abel, W. C. Clark, P. Olsson, D. M. Stafford Smith, B. Walker, O. R. Young, F. Berkes, R. Biggs, J. Morgan Grove, R. L. Naylor, E. Pinkerton, W. Steffen, and F. J. Swanson. 2010. Ecosystem stewardship: sustainability strategies for a rapidly changing planet. Trends in Ecology \& Evolution 25:241-249 http://dx.doi.org/10.1016/j.tr ee.2009.10.008

Cinner, J. E., T. Daw, and T. R. McClanahan. 2009. Socioeconomic factors that affect artisanal fishers' readiness to exit a declining fishery. Conservation Biology 23:124-130. http://dx.doi.org/10.1111/j.15 23-1739.2008.01041.x

Easterly, W. 2006. The big push deja vu: a review of Jeffrey Sachs's The end of poverty: economic possibilities for our time. Journal of Economic Literature 44:96-105. http://dx.doi.org/10.1257/002 $\underline{205106776162663}$

Ellis, F. 2000. Rural livelihoods and diversity in developing countries. Oxford University Press, Oxford, UK.

Fauchald, P., T. Tveraa, C. Henaug, and N. G. Yoccoz. 2004a. Adaptive regulation of body reserves in reindeer, Rangifer tarandus: a feeding experiment. Oikos 107:583-591. http://dx.doi.org/1 $\underline{0.1111 / \mathrm{j} .0030-1299.2004 .12945 . \mathrm{x}}$

Fauchald, P., T. Tveraa, N. G. Yoccoz, and R. A. Ims. 2004b. En фkologisk barekraftig reindrift - Hva begrenser naturlig produksjon og høsting? NINA Fagrapport 76. Norwegian Institute for Nature Research, Trondheim, Norway. [online] URL: http ://www.nina.no/archive/nina/PppBasePdf/fagrapport/076. pdf

Folke, C. 2006. Resilience: the emergence of a perspective for social-ecological systems analyses. Global Environmental Change 16:253-267. http://d x.doi.org/10.1016/j.gloenvcha.2006.04.002

Forbes, B., M. Bölter, L. Müller-Wille, J. Hukkinen, F. Müller, N. Gunslay, and Y. Konstantinov, editors. 2006. Reindeer management in northernmost Europe: linking practical and scientific knowledge in social-ecological systems. Springer, Berlin, Germany.

Forbes, B. C., F. Stammler, T. Kumpula, N. Meschtyb, A. Pajunen, and E. Kaarlejarvi. 2009. High resilience in the Yamal-Nenets socialecological system, West Siberian Arctic, Russia. Proceedings of the National Academy of Sciences of the United States of America 106:22041-22048. http://dx.doi.org/10.1073/pnas.0908286106

Goodwin, B. K., and L. A. Vado. 2007. Public responses to agricultural disasters: rethinking the role of government. Canadian Journal of Agricultural Economics 55:399-417. http://dx.doi.o rg/10.1111/j.1744-7976.2007.00099.x

Ims, R. A., N. G. Yoccoz, K. A. Bråthen, P. Fauchald, T. Tveraa, and V. Hausner. 2007. Can reindeer overabundance cause a trophic cascade? Ecosystems 10:607-622. http://dx.doi.org/10.1007/ s10021-007-9060-9

Kalstad, J. K. 1999. Reindriftspolitikk og samisk kultur - en ulфselig konflikt?. En studie av reindriftstilpasninger og moderne reindriftspolitikk. Diedut 2/99, Sámi Instituhtta, Kautokeino, Norway.

Karlstad, S., and I. Lie. 2009. Verdiskapingen $i$ reindrifta. Report 6: 2009. Norut, Alta, Norway.

Kofinas, G. P., and F. S.Chapin, III. 2009. Sustaining livelihoods and human well-being during social-ecological change. Pages 55-76 in 
Chapin F. S., III, G. Kofinas C. Folke, editors. 2009. Principles of ecosystem stewardship : resiliencebased natural resource management in a changing world. Springer, New York, New York, USA.

Lee, K. N. 1993. Compass and gyroscope integrating science and politics for the environment. Island Press, Washington, D.C., USA.

Ludwig, D., R. Hilborn, and C. Walters. 1993. Uncertainty, resource exploitation, and conservation: lessons from history. Science 260:17 and 36. http:// dx.doi.org/10.1126/science.260.5104.17

Millennium Ecosystem Assessment. 2005. Our human planet: summary for decision makers. Island Press, Washington, D.C., USA.

Ministry of Agriculture. 1974. Report to the Storting $n r$. 33, 1973-74. Ministry of Agriculture, Oslo, Norway.

Ministry of Agriculture. 1976. Royal Proposition, $n r$ 170, 1975-76. Ministry of Agriculture, Oslo, Norway.

Ministry of Agriculture. 1992a. Report to the Storting nr. 28, 1991-92. Ministry of Agriculture, Oslo, Norway.

Ministry of Agriculture. 1992b. Recommendation to the Storting $n r .167,1991-1992$. Ministry of Agriculture, Oslo, Norway.

Morellet, N., J. M. Gaillard, A. J. M. Hewison, P. Ballon, Y. Boscardin, P. Duncan, F. Klein, and D. Maillard. 2007 Indicators of ecological change: new tools for managing populations of large herbivores. Journal of Applied Ecology 44:634-643. http://dx.d oi.org/10.1111/j.1365-2664.2007.01307.x

Movinkel, H., and H. Prestbakmo. 1968. Variation in the carcass weight of reindeer in some summer pasture districts in Finnmark and Troms counties. Scientific reports from the Agricultural College of Norway, Ås, Norway.

Næss, M. W., and B.-J. Bårdsen. 2010. Environmental stochasticity and long-term livestock viability: herd-accumulation as a risk reducing strategy. Human Ecology 38:3-17. http://dx.doi.org /10.1007/s10745-009-9288-4
Nelson, F. 2009. Conservation and aid: designing more effective investments in natural resource governance reform. Conservation Biology 23:1102-1108. http://dx.doi.org/10.1111/j.1523-1739.2009.01195. $\underline{\mathrm{X}}$

Norwegian Ministry of Church Affairs and Education. 1959. Innstilling fra komiteen til å utrede samespфrsmål. Oppnevnt av Kirke -og

Undervisningsdepartementet. Indre Smaalenenes Trykkeri, Mysen, Norway.

Olofsson, A. 2011. Towards adaptive management of reindeer grazing resources. Dissertation. Faculty of Veterinary Medicine and Animal Science, Swedish University of Agricultural Sciences (SLU), Uppsala, Sweden.

Olsson, S. E., and D. Lewis. 1995. Welfare rules and indigenous rights: the Sami people and the Nordic welfare states. Pages 141-185 in J. Dixon and P. Scheurell, editors. Social welfare with indigenous peoples. Routeledge, New York, New York, USA.

Osbahr, H., C. Twyman, W. N. Adger, and D. S. G. Thomas. 2008. Effective livelihood adaptation to climate change disturbance: scale dimensions of practice in Mozambique. Geoforum 39:1951-1964. http://dx.doi.org/10.1016/j.geoforum.2008.07.010

Paine, R. 1994. Herds of the tundra: a portrait of Saami reindeer pastoralism. Smithsonian Institution Press, London, UK.

Paine, R. 2006. Conversations with Ole K. Sara, retired head of the reindeer administration in Norway. Nomadic Peoples 10:233-247. http://dx.do i.org/10.3167/np.2006.100213

Reindeer Husbandry Administration. 2008. Ressursregnskap for reindriftsnoeringen 2007/08. Reindriftsforvaltningen, Alta, Norway.

Reindeer Husbandry Administration. 2009. Totalregnskapet for reindriftsnoringen 2008/09. Reindriftsforvaltningen, Alta, Norway.

Riseth, J. A., and A. Vatn. 2009. Modernization and pasture degradation: a comparative study of two Sami reindeer pasture regions in Norway. Land Economics 85:87-106. 
Riseth, J. A. 2006. Sámi reindeer herd managers: why do they stay in a low-profit business? British Food Journal 108:541-559. http://dx.doi.org/10.11 $\underline{08 / 00070700610676361}$

Robinson, L. W., and F. Berkes. 2010. Applying resilience thinking to questions of policy for pastoralist systems: lessons from the Gabra of Northern Kenya. Human Ecology 38:335-350. http ://dx.doi.org/10.1007/s10745-010-9327-1

Rødven, R. 2010. Causes and consequences of variation in life history of semi-domesticated reindeer. Dissertation. University of Troms $\varnothing$, Troms $\varnothing$, Norway.

Sachs, J. D. 2005. The end of poverty: how we can make it happen in our lifetime. Penguin Books, London, UK.

Sanchez, P., C. Palm, J. Sachs, G. Denning, R. Flor, R. Harawa, B. Jama, T. Kiflemariam, B. Konecky, R. Kozar, E. Lelerai, A. Malik, V. Modi, P. Mutuo, A. Niang, H. Okoth, F. Place, S. E. Sachs, A. Said, D. Siriri, A. Teklehaimanot, K. Wang, J. Wangila, and C. Zamba. 2007. The African millennium villages. Proceedings of the National Academy of Sciences of the United States of America 104:16775-16780. http://dx.doi.org/10.1073/pnas.0 $\underline{700423104}$

Suominen, O., and J. Olofsson. 2000. Impacts of semi-domesticated reindeer and structure of tundra and forest communities in Fennoscandia: a review. Annales Zoologica Fennici 37:233-249.

Tømmervik, H., B. Johansen, J. A. Riseth, S. R. Karlsen, B. Solberg, and K. A. Høgda. 2009. Above ground biomass changes in the mountain birch forests and mountain heaths of Finnmarksvidda, northern Norway, in the period 1957-2006. Forest Ecology and Management 257:244-257. http://dx.d oi.org/10.1016/j.foreco.2008.08.038

Tveraa, T., P. Fauchald, C. Henaug, and N. G. Yoccoz. 2003. An examination of a compensatory relationship between food limitation and predation in semi-domestic reindeer. Oecologia 137:370-376. http://dx.doi.org/10.1007/s00442-003-1373-6

Tveraa, T., P. Fauchald, N. G. Yoccoz, R. A. Ims, R. Aanes, and K. A. Høgda. 2007. What regulate and limit reindeer populations in Norway? Oikos
116:706-715. http://dx.doi.org/10.1111/j.0030-129 9.2007.15257.x

Ulvevadet, B. 2008. Management of reindeer husbandry in Norway - power-sharing and participation Rangifer 28:53-78.

Ulvevadet, B., and V. Hausner. 2011. Incentives and regulations to reconcile conservation and development: thirty years governance of Sami pastoral ecosystems in Finnmark, Norway. In revision Journal of Environmental Management, in press.

United Nations Development Program (UNDP). 2007. Fighting climate change: human solidarity in a divided world. Human Development Report 2007/2008. Palgrave Macmillian, New York, New York, USA. 
Appendix 1. Density-dependent effects and resilience to climatically related disturbances in reindeer husbandry.

In a large-scale study including data from 55 reindeer herding districts in Norway from 19802005, Tveraa et al. (2007) found close relationships between harvest rates, slaughter weights, winter climate, and population dynamics. They concluded that in areas with benign a winter climate, intensive harvesting is necessary to avoid negative density-dependent effects. Compared with other areas in Norway, the reindeer herding area in the present study, Kautokeino, is characterized by a benign and favorable winter climate and low and variable harvest (Tveraa et al. 2007). The combined effects of low harvest and effective control of large predators were: (i) high reindeer stocking density, (ii) low slaughter weights, and (iii) high susceptibility to year-toyear variation in winter climate (Tveraa et al. 2007). Because of these circumstances, the reindeer husbandry in Kautokeino has low resilience/ability to withstand unfavorable weather conditions. This assertion is supported by a number of detailed, individual-based studies of losses in several herds in the area (Tveraa et al. 2003, Fauchald et al. 2004a,b, Bårdsen et al. 2008, 2010). For example, Tveraa et al. (2003) found large losses of calves and even adult females in one year (2000) with deep snow in the spring. The losses were mainly due to starvation and still births; however some calves were also taken by predators. There was a close relationship between the body mass of the mother and the fate of the calves, suggesting that the losses to predators were a compensatory effect of starvation. This conclusion was further supported by the fact that the losses of calves to predators in years with favorable spring conditions were negligible (Tveraa et al. 2003, Fauchald et al. 2004a,b). Moreover, comparisons of the reindeer herding districts within the Kautokeino and Karasjok reindeer herding areas, show strong negative density-dependent relationships with respect to slaughter weights (Bråthen et al. 2007), weights of live animals (Bårdsen et al. 2010), pregnancy rate, and fetal growth (Rødven 2010), and claimed losses to predators (Fauchald et al. 2004b). These relationships are linked to grazing effects on the pastures, because districts with high density of reindeer have reduced plant biomass at high elevations (Tveraa et al. 2007; Tveraa et al., unpublished manuscript), and marked reduction of palatable plant biomass in productive pasture areas (Bråthen et al. 2007). 


\section{APPENDIX 1. Subsidies and compensations to Saami pastoral families/herding units}

Operating subsidies: the main purpose is to increase net income by direct payment to herding units and local districts. Subsidies cover costs for planning, labour, herding and investments in breeding animals. From 1982 subsidies generally required licensed herding units.

\begin{tabular}{|c|c|c|c|c|c|}
\hline Subsidy & Name (Norw.) & Purpose & Requirements and practice & Data source & $\begin{array}{l}\text { Period for } \\
\text { disbursem } \\
\text { ent }\end{array}$ \\
\hline Restocking & Livdyrtilskudd & $\begin{array}{l}\text { Payment for breeding } \\
\text { animals to pastoralists } \\
\text { with a too small herd. }\end{array}$ & $\begin{array}{l}\text { Before } 1974 \text {, less than } 200 \text { reindeers. In } 1974 \text { regulations } \\
\text { require application for loans and enlargement of herds to } \\
300 \text { reindeers. After } 1978 \text { provided as interest-free } \\
\text { credit. }\end{array}$ & $\begin{array}{l}\text { Total payments to the Kautokeino winter } \\
\text { areas were reported by the Saami bailiff'. }\end{array}$ & $\begin{array}{l}1953,1955 \\
1963-1971 \\
1976-1978\end{array}$ \\
\hline $\begin{array}{l}\text { Snow mobile } \\
\text { compensation }\end{array}$ & $\begin{array}{l}\text { Sn } \varnothing \text { scooter- } \\
\text { kompensasjon }\end{array}$ & $\begin{array}{l}\text { Compensation for } \\
\text { gasoline to } \\
\text { snowmobiles. }\end{array}$ & $\begin{array}{l}\text { From } 1968-1981 \text { in the form of reduced tax. From } 1982 \text { it } \\
\text { requires min. } 70 \text { reindeers and is provided as subsidies. } \\
\text { The subsidies increase with larger herds. In } 1988 \text { requires } \\
\text { public counts and harvest rates in local districts. }\end{array}$ & $\begin{array}{l}\text { Total payments published by Saami bailiff } \\
\text { to } 1978 \text {. From } 1982 \text { payments are from } \\
\text { the paper archives at the Reindeer } \\
\text { Husbandry Administrationii. From 1979- } \\
1981 \text { the data were estimated based on a } \\
\text { linear increase in disbursements. }\end{array}$ & $1968-1989$ \\
\hline $\begin{array}{l}\text { Herding unit } \\
\text { subsidies }\end{array}$ & Driftstilskudd & $\begin{array}{l}\text { To cover operating } \\
\text { costs, increase } \\
\text { production capacity and } \\
\text { net income of herding } \\
\text { units. }\end{array}$ & $\begin{array}{l}\text { Graduated according to slaughter quota and reindeer } \\
\text { numbers. Large herds had to slaughter a larger } \\
\text { percentage to qualify for the grant. Losses more than } \\
10 \% \text { could replace slaughter quota. From } 1984 \\
\text { requirements to counts signed by district foreman, and } \\
\text { later public counts. After } 2004 \text { min. income from } \\
\text { reindeer meat or productsiii and max. } 600 \text { reindeers. }\end{array}$ & $\begin{array}{l}\text { Payments published by the Saami bailiff to } \\
\text { 1978, thereafter from the paper archives } \\
\text { at the Reindeer Husbandry } \\
\text { Administration. }\end{array}$ & $\begin{array}{l}1976-1989 \\
2004- \\
\text { present }\end{array}$ \\
\hline $\begin{array}{l}\text { Local } \\
\text { administration } \\
\text { subsidies }\end{array}$ & $\begin{array}{l}\text { Distriktstilskudd } \\
\text { Avløserordning } \\
\text { sykdom/ } \\
\text { svangerskap }\end{array}$ & $\begin{array}{l}\text { Payment for shared } \\
\text { operating costs in local } \\
\text { districts. Includes } \\
\text { temporarily } \\
\text { replacement of labour } \\
\text { because of illness, } \\
\text { pregnancy or holidays. }\end{array}$ & $\begin{array}{l}\text { Requires working plan and budget. Before } 1987 \text { extra } \\
\text { support for low degree of mechanization, except snow } \\
\text { mobile and fences. After } 1987 \text { requirements to slaughter } \\
\text { quota, public counts and/or max. reindeer numbers. }\end{array}$ & $\begin{array}{l}\text { From paper archives at the Reindeer } \\
\text { Husbandry Administration until 1991, } \\
\text { thereafter electronic databasesi. }\end{array}$ & $\begin{array}{l}1980- \\
\text { present }\end{array}$ \\
\hline $\begin{array}{l}\text { Spouse's } \\
\text { supplement }\end{array}$ & Ektefelletilskudd & $\begin{array}{l}\text { Subsidies to pay for } \\
\text { work of spouse with } \\
\text { limited wage income. }\end{array}$ & $\begin{array}{l}\text { Same requirements as for production subsidies (see } \\
\text { below). Both spouses must be actively involved in } \\
\text { reindeer husbandry and there are limits for extra income } \\
\text { (at present, more than } 150000 \text { NOK). }\end{array}$ & $\begin{array}{l}\text { Electronic databases from the Reindeer } \\
\text { Husbandry Administration. }\end{array}$ & $\begin{array}{l}\text { 1999- } \\
\text { Present }\end{array}$ \\
\hline
\end{tabular}


Production subsidies: the major intention of these subsidies is to increase production and delivery at slaughter houses, as well as to spare winter pastures. From 1989 these subsidies could be regarded as ex ante policies, due to their enhanced focus towards reduction of biophysical vulnerability.

\begin{tabular}{|c|c|c|c|c|c|}
\hline Subsidy & Name (Norw.) & Purpose & Requirements and practice & Data source & $\begin{array}{l}\text { Period for } \\
\text { disbursement }\end{array}$ \\
\hline Delivery & Drivetilskudd & $\begin{array}{l}\text { Payment for delivery at } \\
\text { slaughter houses to } \\
\text { improve quality of meat } \\
\text { sold in the market. }\end{array}$ & $\begin{array}{l}\text { Quality marked by approved slaughterhouses with veterinary } \\
\text { control. }\end{array}$ & $\begin{array}{l}\text { Calculated: Number of reindeer } \\
\text { delivered at slaughter houses } x \text { payment } \\
\text { per reindeer as published in regulations. }\end{array}$ & $1963-1990$ \\
\hline Skin subsidies & Skinntilskudd & $\begin{array}{l}\text { Subsides for skins of high } \\
\text { quality. To stimulate } \\
\text { slaughter in autumn to } \\
\text { spare winter pastures. }\end{array}$ & $\begin{array}{l}\text { Early delivery at slaughter houses, mainly before December. } \\
\text { Most payment for delivery before mid-October. In } 1984 \text { the } \\
\text { time limit was extended to } 31 \text {. December. }\end{array}$ & $\begin{array}{l}\text { Self-reports from 1982-1984. Before } \\
1982 \text { estimated based on prescriptions } \\
\text { and deliveries. }\end{array}$ & $1977-1984$ \\
\hline $\begin{array}{l}\text { Calf slaughter } \\
\text { subsidies }\end{array}$ & Kalvetilskudd & $\begin{array}{l}\text { To increase productivity } \\
\text { and spare winter } \\
\text { pastures by slaughtering } \\
\text { calves instead of } 1 \frac{1}{2} \\
\text { year-old reindeers. }\end{array}$ & $\begin{array}{l}\text { Delivery at slaughter houses before 31. January. From } 1986 \\
\text { graduated slaughter quota according to reindeer numbers. } \\
\text { From } 1989 \text { same requirements as for production subsidies. } \\
\text { After } 1992 \text { specification of min. calf weights and slaughter } \\
\text { quota. }\end{array}$ & $\begin{array}{l}\text { From 1978-1986 estimated based on } \\
\text { number of calf slaughtered } \text { div }^{\text {and }} \\
\text { prescriptions. From } 1987 \text { payments were } \\
\text { managed by Reindeer Husbandry } \\
\text { Administration, and data is from the } \\
\text { paper archives. From } 1991 \text { electronic } \\
\text { databases. }\end{array}$ & $\begin{array}{l}1978-1995 \\
\text { 1999-present }\end{array}$ \\
\hline $\begin{array}{l}\text { Production } \\
\text { subsidies }\end{array}$ & $\begin{array}{l}\text { Produksjons- } \\
\text { tilskudd }\end{array}$ & $\begin{array}{l}\text { Subsidies to stimulate } \\
\text { increase production and } \\
\text { harvest rates. }\end{array}$ & $\begin{array}{l}\text { From } 1989 \text { strict requirement to slaughter quota (min. 34\% } \\
\text { and } 1000 \mathrm{~kg} \text { ) and public counts. Districts with reindeer } \\
\text { numbers above their max. limit have to slaughter more. } \\
\text { From } 1994 \text { graduated amount of kg or \% according to herd } \\
\text { size. From 1997, slaughter quota, max. } 600 \text { reindeers and } \\
\text { weight limits. After } 2000 \text { winter, reduced requirements to } \\
\text { slaughter quota and weights in Finnmark. }\end{array}$ & $\begin{array}{l}\text { Data from the reindeer husbandry } \\
\text { administration. } 1989 \text { and } 1990 \text { paper } \\
\text { archive and electronic databases in } \\
1991 .\end{array}$ & $1989-2004$ \\
\hline $\begin{array}{l}\text { Extra } \\
\text { production } \\
\text { subsidies }\end{array}$ & Merslaktetilskudd & $\begin{array}{l}\text { Temporary subsidies to } \\
\text { reduce reindeer } \\
\text { numbers in Finnmark. }\end{array}$ & $\begin{array}{l}\text { Slaughter quota of } \min .34 \% \text {. Detailed prescriptions for } \\
\text { reduction in districts with reindeer numbers above max. } \\
\text { limits. }\end{array}$ & $\begin{array}{l}\text { Data from the reindeer husbandry } \\
\text { administration. } 1989 \text { and } 1990 \text { paper } \\
\text { archive, and electronic databases in } \\
1991 .\end{array}$ & 1989-1991 \\
\hline Bonus & Produksjonspremie & $\begin{array}{l}\text { To increase production } \\
\text { by introducing payment } \\
\text { by results. }\end{array}$ & $\begin{array}{l}\text { The payment is } 25 \% \text { of income from reindeer meat and } \\
\text { products, including handicrafts. Until } 2004 \text { it requires an } \\
\text { income between } 30.000-400.000 \text { NOK, thereafter } 50.000 \text { - } \\
400.000 \text { NOK, and max. } 600 \text { reindeers. }\end{array}$ & $\begin{array}{l}\text { Electronic databases from the reindeer } \\
\text { husbandry administration. }\end{array}$ & 2003-present \\
\hline
\end{tabular}




\begin{tabular}{|c|c|c|c|c|c|}
\hline $\begin{array}{l}\text { Autumn } \\
\text { slaughter } \\
\text { subsidies }\end{array}$ & $\begin{array}{l}\text { Tidligslakte- } \\
\text { tilskudd }\end{array}$ & $\begin{array}{l}\text { To encourage slaughter } \\
\text { in autumn to increase } \\
\text { quality as well as to } \\
\text { spare winter pastures. }\end{array}$ & $\begin{array}{l}\text { Delivery at slaughter houses before } 31 \text {. December. Weight } \\
\text { limits (14-16 kg). From } 1997 \text { same requirements as } \\
\text { production subsidies. From } 2000 \text { slaughter on summer } \\
\text { pastures or } 7 \text { days after. }\end{array}$ & $\begin{array}{l}\text { Before } 1997 \text { estimated based on } \\
\text { slaughter percentage in different } \\
\text { months }{ }^{v} \text { and prescriptions. From } 1997 \\
\text { electronic databases from the reindeer } \\
\text { husbandry administration. }\end{array}$ & 1994-present \\
\hline
\end{tabular}

Preventive measures: the main purpose is to cover expenses for preventive measures to reduce losses to predators or adverse winters (ex ante policies)

\begin{tabular}{|c|c|c|c|c|c|}
\hline Preventive & Name (Norw.) & Purpose & Requirements and practice & Data source & $\begin{array}{l}\text { Period for } \\
\text { disbursement }\end{array}$ \\
\hline $\begin{array}{l}\text { Preventive } \\
\text { measures } \\
\text { climatic } \\
\text { disasters }\end{array}$ & $\begin{array}{l}\text { Katastrofeforebyggende } \\
\text { tiltak }\end{array}$ & $\begin{array}{l}\text { Payment for } \\
\text { measures that } \\
\text { reduce losses of } \\
\text { reindeers due to } \\
\text { catastrophes. }\end{array}$ & $\begin{array}{l}\text { From } 1977 \text {. To obtain compensations a plan had to be } \\
\text { made, including crises fodder, alternative migration } \\
\text { routes and pastures or extra personnel for herding. The } \\
\text { measures should not be to increase economic profits. }\end{array}$ & $\begin{array}{l}\text { Same as compensations } \\
\text { for climatic disasters, but } \\
\text { only minor payments } \\
\text { until } 1993 \text {. Extraordinary } \\
\text { payments in } 1997 \text { and } \\
1998 .\end{array}$ & $\begin{array}{l}1981-1993 \\
1997,1998\end{array}$ \\
\hline $\begin{array}{l}\text { Preventive } \\
\text { measures } \\
\text { predators }\end{array}$ & $\begin{array}{l}\text { Forebyggende tiltak mot } \\
\text { rovviltskader }\end{array}$ & $\begin{array}{l}\text { Payment for } \\
\text { measures that } \\
\text { reduce losses of } \\
\text { reindeers due to } \\
\text { predators. }\end{array}$ & $\begin{array}{l}\text { Application that describes the project/preventive } \\
\text { measure; aim, expected result, realization and } \\
\text { timetable. Could include crises fodder, alternative } \\
\text { migration routes and pastures, shepherd dogs, fences or } \\
\text { extra personnel for herding }\end{array}$ & $\begin{array}{l}\text { From the County } \\
\text { Governor in Finnmark } \\
\text { from } 1997 \text { to 2004, and } \\
\text { from the County } \\
\text { Governor in Troms after } \\
\text { 2004. Electronic } \\
\text { databases. }\end{array}$ & 1997-present \\
\hline
\end{tabular}


Compensation: the main purpose is to cover expenses of economic losses associated with predators or adverse winters (ex post policies).

\begin{tabular}{|c|c|c|c|c|c|}
\hline Compensation & Name (Norw.) & Purpose & Requirements and practice & Data source & $\begin{array}{l}\text { Period for } \\
\text { disbursement }\end{array}$ \\
\hline $\begin{array}{l}\text { Compensation } \\
\text { predators }\end{array}$ & Rovvilterstatninger & $\begin{array}{l}\text { Payment for } \\
\text { losses of } \\
\text { reindeer to } \\
\text { predators. }\end{array}$ & $\begin{array}{l}\text { Application to the Saami bailiff and later to the environmental } \\
\text { authorities. Evaluation normally based on documented losses } \\
\text { in the area. }\end{array}$ & $\begin{array}{l}\text { From } 1970 \text { to } 1981 \\
\text { paper archives at the } \\
\text { Directorate for Nature } \\
\text { Management, } \\
\text { thereafter electronic } \\
\text { databases. }\end{array}$ & 1970-present \\
\hline \multirow[t]{2}{*}{$\begin{array}{l}\text { Compensation } \\
\text { climatic } \\
\text { disasters }\end{array}$} & $\begin{array}{l}\text { Katastrofe - og } \\
\text { tapsfond }\end{array}$ & $\begin{array}{l}\text { Payment for } \\
\text { abnormal losses } \\
\text { on winter } \\
\text { pastures. }\end{array}$ & $\begin{array}{l}\text { In 1977, documented abnormal losses (more than average or } \\
\text { more than } 10 \% \text { of spring breeding herd), public counts } \\
\text { (including sex and age) and a crisis plan. From } 1983 \\
\text { requirements to slaughter. From } 1985 \text { the regional co- } \\
\text { management board defines catastrophic events and accepts } \\
\text { applications of losses. Requires slaughter quota and preventive } \\
\text { measures previous years. In } 1993 \text { only extreme losses were } \\
\text { compensated (more than } 30 \% \text { ). After climatic disasters in 1997, } \\
\text { losses above } 10 \% \text { were compensated. Requires preventive } \\
\text { measures, max. } 600 \text { reindeer, and registered for subsidies. } \\
\text { After } 2002 \text { requires production or operating subsidies one of } \\
\text { the last three years. } \\
\text { The fund has been administrated by different boards vi }\end{array}$ & $\begin{array}{l}\text { Compensations from } \\
\text { the disaster fund was } \\
\text { not granted in } \\
\text { Finnmark from } 1977- \\
1980 \text { because of strict } \\
\text { requirements. From } \\
1981 \text { paper archives, } \\
\text { and from } 1991 \\
\text { electronic databases } \\
\text { from the Reindeer } \\
\text { Husbandry } \\
\text { Administration. }\end{array}$ & $\begin{array}{l}1981^{\mathrm{vii}} \text { - } \\
\text { present }\end{array}$ \\
\hline & $\begin{array}{l}\text { Ekstraordninære st. } \\
\text { prp. }\end{array}$ & $\begin{array}{l}\text { Extraordinary } \\
\text { payment from } \\
\text { the Parliament. }\end{array}$ & $\begin{array}{l}\text { Payment for crisis winter in } 1997 \text { for certain areas/districts and } \\
\text { min. } 100 \text { reindeers. In } 2000 \text {, max. } 600 \text { reindeers and registered } \\
\text { for subsidies. Higher compensations if entitled to production } \\
\text { subsidies previous years. }\end{array}$ & $\begin{array}{l}\text { Parliament documents } \\
\text { and the aggregate } \\
\text { account. }\end{array}$ & $\begin{array}{l}1969 \\
1997-1999 \\
2000-2003\end{array}$ \\
\hline
\end{tabular}

'Annual report from the Saami Bailiff (Årsberetningene fra Lappefogden). From 1950 to 1968 there was one office for Finnmark county. From 1968 the Kautokeino winter pasture area established a separate office. 
ii The data were cross-checked with both the self-reports (Melding om reindrift) and the aggregate account (Totalregnskapet) published by the economic committee for reindeer husbandry. No major deviance was found.

iiisee production bonus for minimum and maximum income.

${ }^{\text {iv }}$ We did not find the original data on number of calves slaughtered (Fraktkontoret for Slakt), but numbers were provided for the period $1978-1986$ in the documents for the General Agreement for the Reindeer Industry in 1986 (Protokoll 1 utvalget).

v The numbers were found in the aggregate account (Totalregnskapet)

${ }^{\mathrm{vi}}$ From 1977 to 1985, the fund was administrated by the Reindeer Husbandry Board (Reindriftsstyret), and from 1985 to 1993 as a separate fund. In 1993 it was transferred to The Reindeer Husbandry Development Fund.

vii Compensations (Katastrofe- og tapsfondet) were available from 1977, but no applications were granted until 1981. 
APPENDIX 3. Interview inquiry of Saami reindeer pastoralists (Vera Hausner and Johnny-Leo Jernsletten)

The study was designed for the purpose of understanding spatial and temporal differences in Saami pastoral communities and reindeer herding practices that could be related to the ecological research on reindeer abundance, productivity, and ecosystem change. Such an inquiry requires a variable-oriented approach that balances comparability with an understanding of the cultural practices of indigenous communities (Ragin 1987). We used mixed methods research (Bergman 2008, Creswell 2009, Teddlie and Tashakkori 2009) and combined quantitative and qualitative approaches to collect and analyze data on six thematic fields that are expected to underlie differences in the Saami pastoral community:

environmental risks, governance, herding practices, economic organization, symbolic, and social capital. The dominant design feature was quantification to (i) obtain representativeness of districts and subgroups of the Saami pastoral communities by multilevel stratified sampling and (ii) to ensure comparability of numeric variables by including closed-ended items to explore predefined research questions. There are, however, few previous studies on Saami pastoral communities, and reliance on our predefined notions of mechanisms that explain spatial and temporal dissimilarities could be seriously flawed. For each of the thematic areas, we therefore included open-ended questions and probes that invited two-way conversations based on an understanding of reindeer herding practices (Bourdieu 1996).

\section{Multilevel stratified sampling}

Our aim was to gain an understanding of spatial and temporal differences in reindeer abundance and productivity. Because this varies both spatially and relative to subgroups such as position, sex, and age, we used multilevel stratified sampling. Participants were selected from an electronic database provided by the Reindeer Husbandry Administration, which included data on reindeer herding units and household members, as well as reindeer abundance and productivity. At the first level, neighboring districts with high contrasts in abundances and productivity over the last 20 years were selected ( 20 of 34 on common winter grazing land in Finnmark). Because these districts vary according to number of licensed herding units, we differentiated the number of Saami pastoralists interviewed according to size of each district. We interviewed 3 reindeer owners in districts with less than 8 herding units, 4 in districts with 8-14 units, and 5 in districts with more than 14 units. We used the official database on herding units, including leaders and household members, to select participants. To limit our sample to active reindeer herders, we excluded those herding units that had, on average, less than 20 reindeer from 2000 to 2006. From June 2007 to August 2008, we interviewed 77 reindeer herders, who represented $35 \%$ of the total number of herding units in the 20 districts.

At the next level, we sampled for heterogeneity to obtain a diversity of opinions about herding practices. In all districts, we included three main categories: the district foreman and two herding unit leaders. The two herding unit leaders were ranked and selected according to the highest and lowest average numbers of reindeer from 2000 to 2006 to investigate differences in opinion between small and large reindeer herd owners. If reindeer herders did not want to participate in the study, we moved to the next herder on the ranked lists. In districts with more than eight units, we assigned reindeer herders to categories according to kinship groups (siida), sex, and age. We targeted the categories that were not yet well represented by the previous selections and randomly selected from these. Reindeer herders who spend most of their time working with the herd are difficult to get in contact. We used 1.5 years to establish contact with herders, which resulted in $84 \%$ participation from the first and second priorities on the lists. The amount of time used to establish contact also limited the sample size of the interview inquiry.

\section{Interviews}

The interviews were conducted by two of the authors; Vera Hausner (Human Environmental Science) and Johnny-Leo Jernsletten (Anthropology). First, we established contact with the participants by 
telephone. It was important that the participants could decide for themselves on the settings of the interviews, which took place in private homes, herding cottages, cafés, offices, and outdoors. The settings may have resulted in some qualitative differences between interviews, but the alternative would have been reduced representativeness of the Saami pastoral community. We could not use a tape recorder, since many Saami pastoralists are skeptical about assurances of anonymity, but both researchers took notes and transcribed them together afterward. The interviews were structured according to thematic frameworks, which allowed for conversational and two-way face-to-face communication. We used a general interview guide approach (Teddlie and Tashakkori 2009), where the wording and the order of questions was adjusted according to the course of each interview. We started with informal conversations in which we probed interests, and closed-ended items were usually introduced at a later stage. One of the interviewers could conduct the interview in the Saami language, but this was only necessary in two cases.

Our standards for ethics were approved by the Norwegian Social Science Data Services and included a letter of information about the study before the start of the interview to secure voluntary participation and a perusal of the final transcript of the interview, if requested.

\section{Analyses}

The data were analyzed using multiple techniques. The interviews were mapped for codes and themes using NVivo 8 (11-15). All interviews were classified as an individual "case" (casebook) with personal characteristics such as sex, age, and type of participant. In addition, all "cases" were classified with geographical variables for the districts: East/West Finnmark, Island/Inland, and High/Low density. The variables had to be standardized according to the closed-ended items by quantitizing the strength of variables using fuzzy logic (Ragin 2000, Teddlie and Tashakkori 2009). Differences and similarities between districts and subgroups was analyzed using qualitative comparative analyses (Grimm and Rihoux 2006), multiple correspondence analysis (Greenacre and Blasius 2006), and homogeneity analyses (Gifi 1990, de Leeuw and Mair 2007).

\section{References}

Bergman, M. M. 2008. Advances in mixed methods research: theories and applications. Sage, Thousand Oaks, California, USA.

Bourdieu, P. 1996. Understanding. Theory Culture \& Society 13:17-37.

Creswell, J. W. 2009. Research design: qualitative, quantitative, and mixed methods approaches. Sage, Thousand Oaks, California, USA.

de Leeuw, J., and P. Mair. 2007. Homogeneity analysis in R: the package homals. Department of Statistics Papers, Department of Statistics, UCLA, Los Angeles, California, USA.

Gifi, A. 1990. Nonlinear multivariate analysis. Wiley, Chichester, UK.

Greenacre, M. J., and J. Blasius. 2006. Multiple correspondence analysis and related methods. Chapman \& Hall/CRC, Boca Raton, Florida, USA.

Grimm, H., and B. Rihoux. 2006. Innovative comparative methods for policy analysis: beyond the quantitative-qualitative divide. Pages XIV, 344 s. Springer, New York, New York, USA.

Ragin, C. C. 1987. The comparative method: moving beyond qualitative and quantitative strategies. University of California Press, Berkeley, California, USA.

Ragin, C. C. 2000. Fuzzy-set social science. University of Chicago Press, Chicago, Illinois, USA. 
Teddlie, C. and A. Tashakkori. 2009. Foundations of mixed methods research: integrating quantitative and qualitative approaches in the social and behavioral sciences. Sage, Thousand Oaks, California, USA. 